\title{
CONTROLLED FEEDING OF THE GROWING PULLET : INTERACTION BETWEEN THE METHOD OF RESTRICTION, THE DWARFISM GENE AND THE TYPE OF BIRD
}

\author{
B. LECLERCQ et J. C. BLUM \\ Station de Recherches avicoles, \\ Centre de Recherches de Tours, I. N.R. A., \\ Nouzilly, 37380 Monnaie
}

Dwarf pullets ( $d w$ gene) did not perform satisfactorily in the laying period if they were fed a low protein diet from hatching : their adult liveweight, the number of eggs and feed consumption during the laying period were significantly lower than those of the control birds fed a balanced diet. This effect was not found in their normal sisters. The difference between dwarf and normal chickens seems to be due to the dwarfism gene since this observation was made with birds coming from two different genetic types: White Rock and Rhode Island Red. The explanation may be found in the mode of action of the dwarfism gene which seems to disturb the secretion of the growth hormone or its utilization.

\section{FEED EFFICIENCY, ENERGY METABOLISM AND PERFORMANCES IN TWO CROSSINGS OF LAYING BIRDS}

\author{
J. Guillaume \\ Station de Recherches avicoles, \\ Centre de Recherches de Tours, I. N. R. A., \\ Nouzilly, 37380 Monnaie
}

Two crossings of laying chickens, $\mathrm{W}$ and $\mathrm{M}$, known to have different feed efficiencies during the laying period, were compared from o to 50 weeks of age. From 2 to 23 weeks they were subjected to two levels of limited feeding. Then the most restricted birds were fed ad libitum a diet containing $2.7 \mathrm{kcal} / \mathrm{g}$ and the less restricted a diet with $3 . \mathrm{I} \mathrm{kcal} / \mathrm{g}$. The energy intake was not related to nutrient density. Though laying at a higher rate, the $W$ hens had a slightly poorer feed efficiency that was partly explained by their higher weight and weight gain. A similar difference was already apparent from 2 to $x 6$ weeks of age ; the $M$ pullets grew faster and had a lower energy expenditure than $\mathrm{W}$ pullets fed the same amount of food. This difference - pronounced only with the most restricted birds - therefore concerns the utilization of metabolisable energy. Some additionnal work is needed to explain its causes. 